\title{
ONEČIŠĆENOST MINAMA U KONTEKSTU GRAĐANSKE SIGURNOSTI I RAZVOJA U DALMATINSKOJ ZAGORI
}

Josip ČERINA

Hrvatski centar za razminiranje - Podružnica Zadar, Zadar

UDK: 338.43(497.5-3Dalmatinska zagora):623.958

351.78(497.5-3Dalmatinska zagora):623.958

623.958(497.5-3Dalmatinska zagora)

Prethodno priopćenje

Primljeno: 23. 6. 2010.

Članak analizira odnose miniranosti terena i poljoprivrednu aktivnost na području Dalmatinske zagore koje je onečišćeno minama. Osim miniranosti, problem je što su brojne obradive površine zbog dugogodišnje neupotrebe obrasle u korov i makiju. Prema tome, društveni i gospodarski razvitak nije moguć bez pomoći šire društvene zajednice. Analizom problema mina koji se odnosi na građansku sigurnost došlo se do odgovora na pitanje kako smanjiti utjecaj onečišćenosti prostora pod minama na život i rad lokalnoga stanovništva. Metodom klasifikacije i deskripcije, pomoću geoinformacijskih alata, utvrđene su kategorije i veličina površina koje su očišćene od minsko-eksplozivnih ostataka rata za svaku pojedinu ugroženu zajednicu, a to je omogućilo daljnju kvalitativnu analizu utjecaja problema mina na građansku sigurnost i gospodarski razvoj. U obradbi podataka primijenjene su programske operacije Map Info, kojima se dolazi do prostornih podataka o analiziranim površinama. Pojas uz cestovnu infrastrukturu očišćen je i omogućuje sigurno odvijanje prometa, za razliku od planinskih i poljskih putova, koji su na nekim područjima još uvijek minirani.

Ključne riječi: problem mina, tradicijske djelatnosti, građanska sigurnost

Josip Čerina, Hrvatski centar za razminiranje Podružnica Zadar, Stjepana Radića 11, 23000 Zadar, Hrvatska. E-mail: jcerina@hcr.hr 
Dalmatinska zagora je područje odvojeno prirodnom granicom planinskih uzvišenja Trtara, Opora, Kozjaka, Mosora, Biokova i Rilića od obalnoga pojasa. Kada govorimo o geografskim obilježjima prostora, treba razlikovati shvaćanje Zagore i Dalmatinske zagore, iako se u svakodnevnom govoru mogu pojaviti kao istoznačnice. Zagora je uže geografsko područje koje se prostire u zaleđu Trtara, Opora, Kozjaka, Mosora, a sastavljena je od Šibenske i Splitske zagore. ${ }^{1}$ Dalmatinska zagora je pojam koji obuhvaća širi prostor, a prostire se od linije Trtara, Opora, Kozjaka, Mosora, Biokova i Rilića pa do Dinare, Kamešnice i Kruševice, od kninskog područja na sjeveru do vrgoračkog područja na jugu. ${ }^{2}$ Onečišćenost prostora minama iz Domovinskog rata je zabilježena na području gradova: Drniša, Vrlike i Sinja i na području općina: Promine, Ružića, Hrvaca, Civljana i Muća. Posljedice onečišćenja prostora minama uzrokuje brojne socijalne, ekonomske, razvojne i sigurnosne probleme. Mnoga područja i danas su nedostupna zbog miniranosti i sumnje da su onečišćena eksplozivnim ostacima rata. Nakon osnivanja Hrvatskoga centra za razminiranje 1998. godine kao nacionalnoga tijela za protuminsko djelovanje, trebalo je šest godina da se precizno definira veličina i struktura problema mina. Precizno definiranje minski sumnjivih površina omogućilo je donošenje realnih ciljeva protuminskoga djelovanja i nacionalni program protuminskoga djelovanja. Sada je na snazi Nacionalni program protuminskoga djelovanja od 2009. do 2019. godine, u kojem je za polazno stanje minski sumnjivoga prostora u Republici Hrvatskoj navedena veličina od $954,5 \mathrm{~km}^{2}$, koje se u tom razdoblju planira potpuno riješiti raznim aktivnostima protuminskoga djelovanja.

Svake godine u Hrvatskom centru za razminiranje izrađuju se pregledni zemljovidi minski sumnjivih područja za županije, gradove i općine na topografskim kartama u mjerilu 1:25000 s precizno ucrtanim pozicijama ploča upozorenja na opasnost od mina te se prosljeđuju lokalnoj zajednici. Uspostavljena je stalna veza s lokalnom zajednicom u procesu obavješćivanja o stanju obilježenosti minski sumnjivih područja. Jedinice lokalne uprave i samouprave po potrebi traže dopunu obilježavanja i provjeru obilježenosti na svojem području. Ovaj način komunikacije važan je jer je održavanje potpune obilježenosti jedan od učinkovitih načina prevencije od stradanja. "Nedostajuće table upozorenja narušavaju sigurnost, kako stanovnika koji žive uz te prostore, tako i putnika koji prolaze područjima koja su zagađena minama" (Cerina, 2009., 35). Na područjima koja su onečišćena minama i na minski sumnjivim područjima stanovništvo se ne može slobodno kretati, ne može obnoviti ranije gospodarske aktivnosti, a niti razvijati nove. Time se povećava socijalna i demografska depresija i onemogućuje povratak stanovništva. Stoga Hrvatski centar 
DRUŠ. ISTRAŽ. ZAGREB GOD. 21 (2012), BR. 1 (115)

STR. 259-275

ČERINA, J.: ONEČIŚCEENOST... za razminiranje svake godine provjerava stanje obilježenosti svih pozicija oznaka opasnosti od mina, s posebnom pažnjom u proljeće, kada se intenziviraju poljoprivredni radovi. Veza s lokalnim zajednicama ne odnosi se samo na obilježavanje minski sumnjivih površina nego i na druge aktivnosti koje omogućuju zajednicama da budu informirane o lokaciji, dosegu i učinku onečišćenih područja. Ona teži osigurati da projekti protuminskoga djelovanja budu odraz stvarnih potreba i prioriteta zajednice. Ova dvosmjerna veza uspostavljena je na relaciji Hrvatski centar za razminiranje - županije onečišćene minama - općine / gradovi. Lokalne zajednice redovito se informiraju o lokaciji, dosegu i opasnosti zagađenih područja i aktivno sudjeluju u predlaganju projekta razminiranja. Posebna se pažnja pridaje sastavljanju liste prioriteta u korist lokalne zajednice. $\mathrm{O}$ važnosti suradnje s lokalnom zajednicom u svjetskoj je literaturi napisano niz znanstvenih i stručnih radova i rasprava (Hewitt i sur., 2001.; Vupenyu, 2004.; Bocchina, 2007.; Filippino, 2000.). Suradnja vlasti, nevladinih organizacija, centara za razminiranje te lokalne zajednice poglavito ima ulogu na obnavljanju tradicionalnih poljoprivrednih djelatnosti na područjima očišćenim od mina (Weyl, 1999.; Benini i sur., 2002.; Bier, 2003.; Trevelyan i sur., 2002.). ${ }^{3}$

\section{GEOGRAFSKA OBILJEŽJA PROSTORA I DEPOPULACIJA STANOVNIŠTVA}

Zagora je geografski, ali i povijesno, pojam za prostor koji se prostire u zaleđu planinskih masiva Trtara, Opora, Kozjaka, Mosora (Matas, 2005.). Dalmatinska zagora je pojam koji obuhvaća šire područje, odvojeno prirodnom granicom planinskih uzvišenja Trtara, Opora, Kozjaka, Mosora, Biokova i Rilića od obalnoga pojasa i prostire se sve do Dinare, Kamešnice i Kruševice, od rijeke Krke na zapadu do Zveča na jugu (Slika 1). Dalmatinska zagora dijeli se na nekoliko manjih geografskih cjelina, koje se u literaturi nazivaju zagora ili krajina: Kninska, Drniška, Vrličko-sinjska (Cetinska krajina), Imotska, Vrgoračka i Zagora splitske konurbacije. Prostor zagore, koji je predmet ovog istraživanja, pripada Drniškoj zagori (naselja Drniš, Promina, Ružić) i Vrličko-sinjskoj (Civljane, Hrvace, Vrlika, Sinj) i Zagori splitske konurbacije (Muć).

U Domovinskom ratu dijelovi Dalmatinske zagore bili su područja neposrednih ratnih djelovanja, odnosno zone razdvajanja snaga, a time i minski onečišćen teritorij, konkretno: područja gradova Drniša, Vrlike i Sinja te općina Promina, Hrvace, Muć, Ružić i Civljane. Analiza kretanja broja stanovnika na promatranom području pokazuje depopulaciju zbog ratnih zbivanja. Iseljavanje stanovništva najočitije se vidi iz odnosa broja stanovnika neposredno prije Domovinskog rata i nakon njega (Tablica 1). Neka od područja, odnosno gradovi i općine, zabilježili su velik pad broja stanovnika, poput po- 
- SLIKA 1

Područje Dalmatinske zagore usklađeno sa Zakonom o područjima županija, gradova, općina i naselja u RH i prostornoga shvaćanja autora $M$ Matasa (2009.

132-133)

dručja gradova Drniša i Vrlike i općina Promine, Ružića i Civljana. Općina Civljane gotovo je potpuno izgubila stanovništvo, koje se od predratnih 1672 svelo na samo 137 stanovnika, odnosno zabilježen je pad od $91,81 \%$.

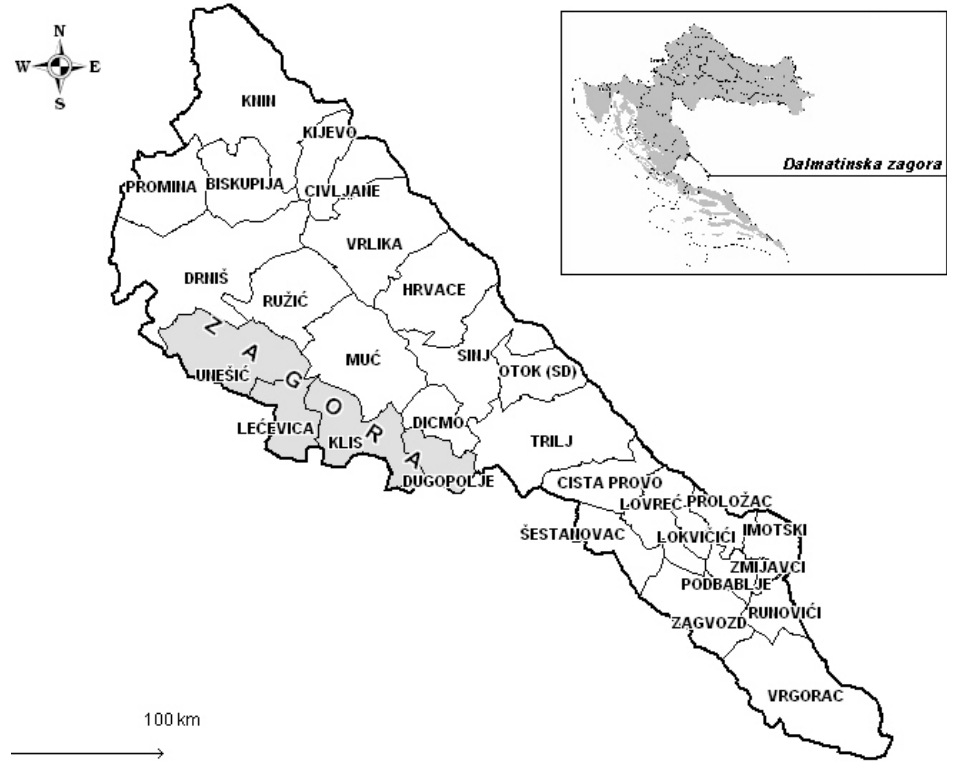

\begin{tabular}{lrrrrr}
\hline Grad / & $\begin{array}{r}\text { Broj } \\
\text { Općina }\end{array}$ & $\begin{array}{r}\text { Broj } \\
\text { stanovnika } \\
\text { stanovnika }\end{array}$ & $\begin{array}{r}\text { Promjene } \\
\text { stanovnika } \\
\text { 2001.-1991. }(\%)\end{array}$ & $\begin{array}{r}\text { Površina grada/ } \\
\text { općine }\left(\mathrm{km}^{2}\right)\end{array}$ & $\begin{array}{r}\text { Gustoća } \\
\text { 2001. }\end{array}$ \\
\hline Drniš & $\left.1991 . / \mathrm{sm}^{2}\right)$
\end{tabular}

Izvor: Internetska stranica Državnog zavoda za statistiku www.dzs.hr (posjećeno 5. 4. 2010.).

(1) TABLICA 1

Kretanje broja stanovnika od 1991 do 2001 . na prostoru Dalmatinske zagore onečišćenom minama
Na cijelom promatranom području broj stanovnika smanjio se za više od trećine $(-39,85 \%)$, a to je dodatno pogoršalo rijetku naseljenost. Prema definiciji OECD-a, koja se temelji na gustoći naseljenosti stanovništva, promatrana područja općina i gradova mogu se proglasiti ruralnim područjem jer ne prelaze prag od 150 stanovnika po $\mathrm{km}^{2}$. Samo područje Grada Sinja doseže 140,18 stanovnika po $\mathrm{km}^{2}$. Gustoća naseljenosti na prostoru Grada Drniša iznosi 24,21 stanovnik po $\mathrm{km}^{2}$, a po- 
dručje općina Hrvace i Muć naseljeno je s nešto manje od 20 stanovnika po $\mathrm{km}^{2}$. Prostor Grada Vrlike i ostalih općina opustjeli je prostor.

\section{TRADICIJSKE DJELATNOSTI U DALMATINSKOJ ZAGORI}

\begin{tabular}{|c|c|c|c|c|c|c|c|}
\hline \multicolumn{3}{|c|}{$\begin{array}{l}\text { (1) TABLICA } 2 \\
\text { Poljoprivredna } \\
\text { kućanstva prema } \\
\text { ukupno raspoloživom } \\
\text { zemlijštu i načinu } \\
\text { njegove upotrebe }\end{array}$} & \multicolumn{5}{|c|}{$\begin{array}{l}\text { Područja Dalmatinske zagore koja su onečišćena eksplozivnim } \\
\text { ostacima rata tradicionalno su poljoprivredno ekstenzivni pro- } \\
\text { stori, polikulturne proizvodnje, uglavnom malih čestica, koja } \\
\text { nisu omogućavala intenzivniju poljoprivrednu aktivnost (Ta- } \\
\text { blica 2). Analiza odnosa kućanstava i poljoprivrednoga zemljišta } \\
\text { upućuje na dominaciju izrazito malih posjeda, prosječne ve- } \\
\text { ličine } 1,18 \text { ha u Gradu Drnišu, } 2,40 \text { ha u Općini Promina, } 1,69 \\
\text { u Općini Ružić, } 1,06 \text { u Općini Hrvace, } 1,78 \text { u Vrlici, } 2,33 \text { ha u } \\
\text { Civljanima, do } 0,87 \text { ha u Muću i } 0,82 \text { ha na području Grada } \\
\text { Sinja. Dodatno opterećenje bilo kakvom razvoju poljoprivre- } \\
\text { de predstavlja i veliki broj parcela poljoprivrednoga zemljišta. } \\
\text { Broj parcela kreće se od } 2,4 \text { parcela po kućanstvu na području } \\
\text { Grada Vrlike do } 7,1 \text { parcele u Općini Civljane. Prosječna ve- } \\
\text { ličina parcela po kućanstvu u svim gradovima i općinama pro- } \\
\text { matranoga područja manja je od } 1 \text { ha, a na području Općine } \\
\text { Muć najveća je usitnjenost posjeda koji su prosječne veličine } \\
\text { 0,1 ha po kućanstvu. Ovakva usitnjenost i isparceliranost po- } \\
\text { sjeda upućuje i na problem otežane intenzivnije poljoprivred- } \\
\text { ne proizvodnje, a time i na gospodarski oporavak područja } \\
\text { vezan uz tradicionalni način gospodarenja. }\end{array}$} \\
\hline Područje & $\begin{array}{r}\text { Broj } \\
\text { kućan- } \\
\text { stava }\end{array}$ & $\begin{array}{r}\text { Ukupno } \\
\text { raspoloživa } \\
\text { površina } \\
\text { zemljišta, } \\
\text { ha* }\end{array}$ & $\begin{array}{r}\text { Ukupno ko- } \\
\text { rišteno poljo- } \\
\text { privredno } \\
\text { zemljište, } \\
\text { ha** }\end{array}$ & $\begin{array}{r}\text { Ostalo } \\
\text { zemljište, } \\
\text { ha }\end{array}$ & $\begin{array}{l}\text { Broj par- } \\
\text { cela korište- } \\
\text { noga poljo- } \\
\text { privrednog } \\
\text { zemljišta }\end{array}$ & $\begin{array}{l}\text { Prosječan } \\
\text { broj parcela } \\
\text { kućanstava }\end{array}$ & $\begin{array}{r}\text { Prosječna } \\
\text { veličina } \\
\text { parcele po } \\
\text { kućanstvu } \\
\text { (u ha) }\end{array}$ \\
\hline Drniš & 1649 & 1951,39 & 1322,65 & 628,74 & 7525 & 4,6 & \\
\hline Promina & 400 & & & & 1501 & 3,7 & \\
\hline Ružić & 436 & 740,95 & 598,5 & 142,45 & 2342 & 5,4 & \\
\hline Hrvace & 880 & 929,65 & 609,41 & 320,24 & 4133 & 4,9 & \\
\hline Muć & 726 & 634,83 & 462,19 & 172,64 & 3688 & 5,1 & \\
\hline Vrlika & 611 & 1089,91 & 685,75 & 404,16 & 2621 & 2,4 & \\
\hline Civljane & 95 & 221,75 & & 146 & 677 & 7,1 & \\
\hline Sinj & 2931 & 2417,9 & 1795,55 & 622,35 & 10503 & 3,6 & \\
\hline
\end{tabular}

* Ukupno raspoloživa površina zemljišta, ha: obuhvaća ukupno korišteno poljoprivredno + ostalo zemljište

** Ukupno korišteno poljoprivredno zemljište, ha: obuhvaća zemljište u vlasništvu + uzeto u zakup - dano u zakup

Izvor: Popis poljoprivrede iz 2003. godine na internetskoj stranici www.dzs.hr (posjećeno 5. 4. 2010.)

Prema popisu poljoprivrede iz 2003., najveći dio poljoprivrednoga zemljišta odnosi se na oranice, livade i pašnjake, a 
DRUŠ. ISTRAŽ. ZAGREB GOD. 21 (2012), BR. 1 (115)

STR. $259-275$

ČERINA, J.: ONEČIŚCEENOST...

- TABLICA 3

Broi goveda, ovaca i koza na području miniranih općina Dalmatinske zagore tek se manji dio iskorištava za poljoprivrednu proizvodnju, poput voćarstva i povrtlarstva. Razloge tomu možemo tražiti i u karakterističnom krškom reljefu, ali i dobnoj strukturi ruralnoga stanovništva, koje je uglavnom starije dobi. Naime, voćarsko-vinogradarska djelatnost traži veći intenzitet rada i ulaganja kapitala u proizvodnju, što stanovništvo starije dobi ne može ostvariti. Područje Dalmatinske zagore tradicionalno je vinogradarski kraj s nekoliko agrarno važnih lokacija. Tako se na prostoru šibenskoga dijela Zagore izdvajaju vinogradarske mikroregije: Prominska, Drniška, Kninska s karakterističnim sortama debita, plavine crne, lasine crne, merlota. U splitskom dijelu promatranoga područja izdvaja se sinjsko-vrlička vinogradarska mikroregija sa sortama okatac crni, debit bijeli. Dijelom zbog miniranosti terena, ali i ruralnog iseljavanja stanovništva, vinogradarstvo je postalo u obiteljskim gospodarstvima sporedna djelatnost.

Stočarska proizvodnja stoljećima je na prostoru Dalmatinske zagore bila dominantan izvor egzistencije. Cetinsko, Sinjsko i Vrličko polje orijentirano je na govedarstvo, poglavito na uzgoj mliječnih krava, dok su uzgoj ovaca i koza karakteristični za viša planinska područja Svilaje, Dinare, Kamešnice, gdje je bilo razvijeno transhumantno stočarenje. I danas su drniški, prominski i vrlički kraj vodeći u ovčarskoj proizvodnji (Tablica 3).

\begin{tabular}{lrrr}
\hline Područje & Goveda & Ovce & Koze \\
\hline Drniš & 1026 & 11343 & 1384 \\
Promina & 306 & 4744 & 657 \\
Ružić & 620 & 2077 & 1405 \\
Hrvace & 877 & 4462 & 1044 \\
Muć & 536 & 2054 & 1152 \\
Vrlika & 596 & 4795 & 1179 \\
Civljane & 27 & 530 & 279 \\
Sinj & 1190 & 1079 & 186
\end{tabular}

Izvor: Popis poljoprivrede iz 2003. godine na internetskoj stranici www.dzs.hr (posjećeno 5. 4. 2010.).

Najviše se ovce pramenke uzgajaju zbog mesa, dok je samo manji dio uzgoja usmjeren na preradbu mlijeka i proizvodnju sira. Broj od 20 ili više grla stoke po domaćinstvu rijedak je, što upućuje na činjenicu da još uvijek nema interesa za ozbiljnije tržišno bavljenje stočarskom proizvodnjom. Proizvodnja vune ima zanemarivo malu važnost, vuna ne služi kao sirovina u procesima daljnje preradbe u odjevne predmete i najveći se dio odlaže u okoliš kao otpad.

Eksploatacija kamena i građevinskoga materijala bila je jed- 
DRUŠ. ISTRAŽ. ZAGREB GOD. 21 (2012),

BR. 1 (115),

STR. $259-275$

ČERINA, J.: ONEČIŚCEENOST... tivnosti na ovom području. Prema Crničkom i Šinkovcu (1993.), najveće naslage karbonatnih sirovina i vapnenca nalaze se na području Grada Drniša (Pakovo selo, Miočić, Parčić), dok su se naslage kremena i gipsa eksploatirale na području Općine Ružić (Gradac, Baljci, Ružić), na području Sinja, Vrlike i Drniša. Vapnenac se vadio i na eksploatacijskim poljima u Promini (Razvođe). Građevinska sirovina šljunak i pijesak eksploatirao se na području Muća i Sinja, a s ležišta Krušvar kod Sinja vadio se u kamenolomima građevinski i arhitektonski kamen. Najveći dio ležišta ugljena (Ruduša) kod Sinja iscrpljen je, kao i ležišta boksita u Promini.

\section{PROBLEM MINA I VAŽNOST KOMUNIKACIJE}

Onečišćenost prostora minama uzrokuje brojne društvene, gospodarske, razvojne i sigurnosne probleme. Poljoprivredne površine, dijelovi infrastrukturne mreže, kršovita područja, obalni pojas uz Perućko jezero i danas su nedostupni zbog miniranosti ili sumnje da su onečišćeni eksplozivnim ostacima rata. Prva procjena veličine minski sumnjivog prostora Dalmatinske zagore iznosila je $1056 \mathrm{~km}^{2}$, a druga $80 \mathrm{~km}^{2}$ na području gradova Drniša, Sinja i Vrlike te općina Promina, Civljane, Ružić, Muć i Hrvace (Slika 2). Stanje minski sumnjivoga prostora u siječnju 2010 . godine iznosi $60 \mathrm{~km}^{2}$ i planira se, prema Nacionalnom programu protuminskoga djelovanja od 2009. do 2019. godine, potpuno očistiti raznim aktivnostima protuminskoga djelovanja do kraja 2019. godine.

Humanitarno razminiravanje je proces koji uključuje aktivnosti od prikupljanja podataka nužnih za procjenu minske situacije do čišćenja i predaje razminiranoga područja. "Osnovni cilj svih informacija za javnost jest održanje kontinuirane razine spoznaje o minskoj opasnosti u razdoblju dok minirani prostori ne budu očišćeni od mina i predani krajnjim korisnicima na sigurnu upotrebu" (Čerina, 2009., 37). Čišćenje minski sumnjivih površina podrazumijeva uklanjanje ili uništavanje svih opasnosti od mina i neeksplodiranih ubojitih sredstava s određenoga područja.

Uspostavljanjem komunikacije s lokalnom zajednicom o svim aktivnostima protuminskoga djelovanja pridonosi se građanskoj sigurnosti dok minirani prostori ne budu posve očišćeni od mina, to više što su u pitanju ljudska prava na život i rad pod jednakim uvjetima. Opasnost od stradanja bitno je smanjena u zadnjih nekoliko godina zbog raznih aktivnosti protuminskoga djelovanja. Međutim, ima još onih koji ignoriraju opasnost, koji su bezobzirni i neodgovorni prema sebi i svojoj imovini, a u "mnogim slučajevima razlog takova ponašanja je nedovoljna informiranost građana" (Cerina i Zgrabljić Rotar, 2009., 144). Globalna iskustva o tome, prema Vodi- 
DRUŠ. ISTRAŽ. ZAGREB GOD. 21 (2012),

BR. 1 (115),

STR. $259-275$

ČERINA, J.:

ONEČIŚCEENOST... ču kroz borbu protiv mina (GICHD, 2004.), upućuju na četiri kategorije: nesvjesni (osoba nije upoznata s opasnostima od mina); neinformirani (osoba zna o minama, ali ne zna o sigurnom ponašanju); bezobzirni (osoba zna o ponašanjima sigurnoga postupanja s minama, ali ih ignorira) i namjerni (osoba nema puno mogućnosti, već namjerno prihvaća nesigurno ponašanje). Upravo zbog ovakva ponašanja pojedinaca valja sustavno upozoravati na opasnost od mina te ljude upućivati na primjerene oblike ponašanja u miniranom okruženju. Jedino se uspostavljanjem i održavanjem stalne veze s lokalnom zajednicom može smanjiti rizik od stradanja i omogućiti siguran život i rad u blizini minski sumnjivih područja. Suradnja $\mathrm{s}$ lokalnom zajednicom $\mathrm{u}$ procesu obavješćivanja o stanju obilježenosti minski sumnjivih područja vrlo je važna. Jedinice lokalne uprave i samouprave traže, po potrebi, dopunu obilježavanja i provjeru obilježenosti na svojem području. Osim toga, Hrvatski centar za razminiranje svake godine provodi provjeru stanja obilježenosti svih pozicija oznaka minske opasnosti, s posebnom pažnjom u proljeće, kada se intenziviraju ruralne djelatnosti. ${ }^{4}$

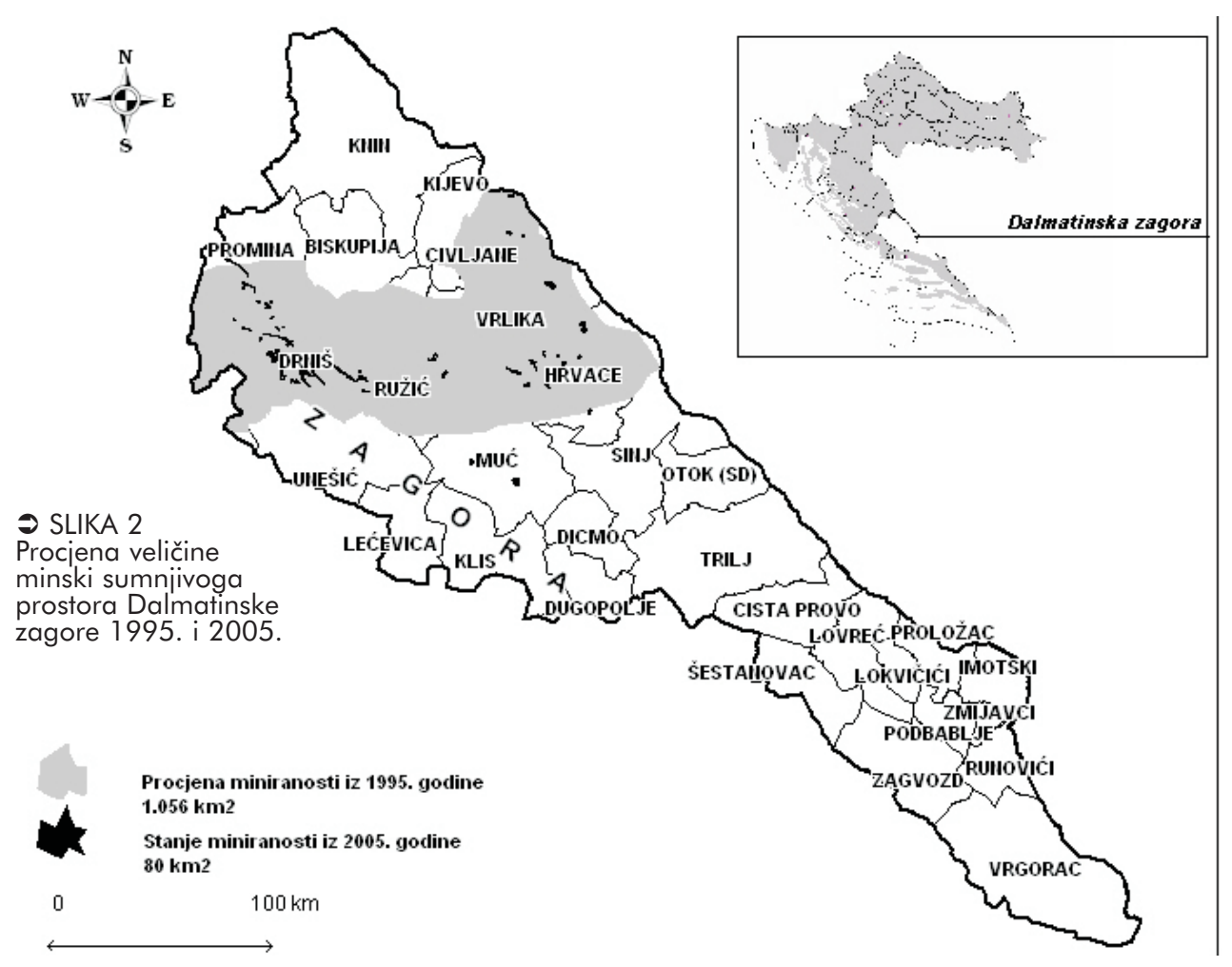

Izvor: Geoinformacijski sustav i baza podataka HCR-a 


\section{METODOLOGIJA}

(1) SLIKA 3

Ekspanzija i

selektiranje područja

analize - primier

naselja Dabar
U ovom se radu analiziraju podaci koji se odnose na rezultate protuminskoga djelovanja, s posebnim naglaskom na građanskoj sigurnosti. Analizom su obuhvaćena područja gradova Drniša, Sinja i Vrlike te općina Promina, Civljane, Ružić, Muć i Hrvace. Izvor podataka je Minsko informacijski sustav HCR-a, koji se sastoji od Geoinformacijskog sustava i baze podataka. Postavljena su tri radna pitanja: prvo, kako klasificirati minski sumnjiv prostor u blizini naselja i cestovnih pravaca; drugo, kako pokazati da problem mina ne utječe na sigurnost građana, i treće, kako dokazati da problem mina utječe na ruralne djelatnosti. Izvršeno je selektiranje svih razminiranih površina na području Dalmatinske zagore te su kao takve razdijeljene na četiri sloja (layer): državne ceste, lokalne ceste, sigurnosni pojas uz naselja, poljoprivredne površine i ostala razminirana područja. Zatim je prema kartografskim podlogama provedena ekspanzija (bufferiranje) prema sljedećim kriterijima: za državne ceste $100 \mathrm{~m}$, a za lokalne ceste $50 \mathrm{~m}$ od osi te za sigurnosni pojas uz naselja radijus od 200 metara (Slika 3).

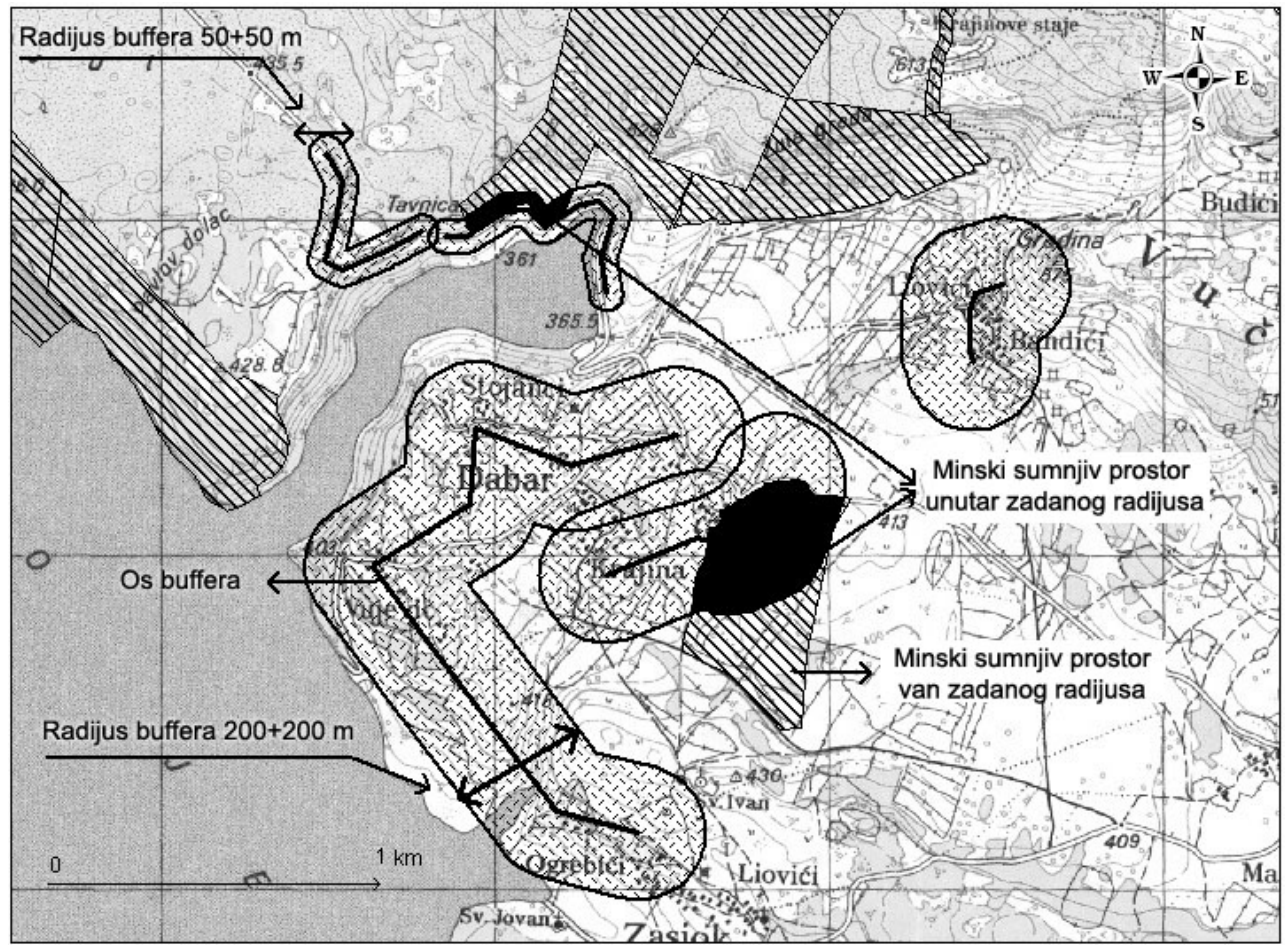

Izvor: Minsko informacijski sustav HCR-a - upotreba GIS aplikacija

Uslijedilo je selektiranje svih površina unutar zadanoga pojasa te razvrstavanje prema administrativnim granicama općina i gradova. Metodom klasifikacije i deskripcije, primje- 
DRUŠ. ISTRAŽ. ZAGREB GOD. 21 (2012),

BR. 1 ( 115$)$

STR. 259-275

ČERINA, J.:

ONEČIŚĆENOST... nom programske operacije Map Info (set geoinformacijskih alata), utvrđena je veličina površine koja je očišćena od minsko-eksplozivnih sredstava za svaku pojedinu općinu i grad. Dobiveni brojčani pokazatelji omogućili su daljnju kvalitativnu analizu mogućeg utjecaja onečišćenosti prostora minama na bavljenje ruralnim djelatnostima i građansku sigurnost.

\section{REZULTATI I RASPRAVA}

U kontekstu društvenog i gospodarskog razvitka Dalmatinske zagore, problem mina možemo promatrati u odnosu na mogućnosti bavljenja ruralnim djelatnostima te sigurnost kretanja ljudi i roba. Kako bismo mogli provesti kvalitativnu analizu rezultata istraživanja, poslužili smo se statističkim podacima s internetske stranice Državnog zavoda za statistiku (www.dzs.hr, posjećeno 5. 4. 2010.) o popisu stanovnika i poljoprivrede za područja općina i gradova koji imaju problem mina.

Radovima razminiranja na području Dalmatinske zagore obuhvaćena je površina od 16,8 km², odnosno $21,73 \%$ ukupnoga minski sumnjivoga prostora (Tablica 4). Najviše je očišćenog prostora na području Grada Drniša, 6,55 km², što iznosi $24,37 \%$ od polaznoga stanja minski sumnjivoga prostora. $\mathrm{Na}$ području Općine Hrvace razminiran je prostor površine 5,46 $\mathrm{km}^{2}$, a još je $15,04 \mathrm{~km}^{2}$ nerazminiranoga prostora. Razminiranje na području Grada Vrlike odnosilo se na površinu od $0,73 \mathrm{~km}^{2}$, jer problem mina nije bio zapreka razvoju i povratku. Najviše onečišćena prostora jest na području gradova Drniša i Vrlike i Općine Hrvace. Uglavnom se radi se o minski sumnjivu prostoru, koji na padinama Moseća, Svilaje i Dinare i poPregled razminirania
od 1998. do 2010 . preostali MSP tencijalno može utjecati na intenzivnije bavljenje stočarstvom.

\begin{tabular}{|c|c|c|c|c|c|}
\hline \multirow[b]{3}{*}{ Općina / Grad } & \multirow{3}{*}{$\begin{array}{l}\text { Polazno stanje minski } \\
\text { sumnjivoga prostora } \\
\mathrm{km}^{2}\end{array}$} & \multicolumn{4}{|c|}{ Stanje minski sumnjivoga prostora } \\
\hline & & \multicolumn{2}{|c|}{ Razminirano } & \multicolumn{2}{|c|}{ Nerazminirano } \\
\hline & & $\mathrm{km}^{2}$ & $\%$ & $\mathrm{~km}^{2}$ & $\%$ \\
\hline Drniš & 26,87 & 6,55 & 24,37 & 20,32 & 75,63 \\
\hline Promina & 6,00 & 2,30 & 38,33 & 3,70 & 61,67 \\
\hline Ružić & 9,07 & 1,08 & 11,91 & 7,99 & 88,09 \\
\hline Vrlika & 12,93 & 0,73 & 5,64 & 12,20 & 94,36 \\
\hline Hrvace & 20,5 & 5,46 & 26,63 & 15,04 & 73,37 \\
\hline Sinj & 0,59 & 0,59 & 100 & 0,00 & 0,00 \\
\hline Civljane & 0,25 & 0,00 & 0,00 & 0,25 & 100,00 \\
\hline Muć & 0,86 & 0,04 & 4,65 & 0,82 & 95,35 \\
\hline Ukupno & 77,07 & 16,75 & 21,73 & 60,32 & 78,27 \\
\hline
\end{tabular}

Izvor: Geoinformacijski sustav i baza podataka HCR-a (stanje siječanj 2010.)

U Tablici 5 prikazani su rezultati razminiranoga prostora 
DRUŠ. ISTRAŽ. ZAGREB GOD. 21 (2012), BR. 1 (115)

STR. 259-275

ČERINA, J.: ONEČIŚĆENOST...

\section{(1) TABLICA 5}

Površina poljoprivrednih površina i stanje MSP-a poljoprivrednih površina odnosi se na $1,52 \mathrm{~km}^{2}$, a to iznosi $36,31 \%$ poljoprivrednih površina koje su bile onečišćene minama. Može se zaključiti da veličina nerazminiranih poljoprivrednih površina veličine $2,66 \mathrm{~km}^{2}$ ipak značajnije ne utječe na bavljenje ruralnim djelatnostima, jer se nije dogodio masovni povratak stanovništva nakon rata. Osim toga, tek se manji dio stanovništva starije dobi bavi poljoprivredom i stočarstvom iz egzistencijalnih razloga. To uzrokuje nestašicu domaćih stočarskih i poljoprivrednih proizvoda u obalnom području. Opravdana je sumnja građana da se na tržnici nude proizvodi koji ipak nisu podrijetlom iz Dalmatinske zagore.

\begin{tabular}{|c|c|c|c|c|c|c|}
\hline \multirow[b]{3}{*}{ Općina / Grad } & \multirow{3}{*}{$\begin{array}{r}\text { Veličina } \\
\text { rivrendnih } \\
\text { površina } \\
\mathrm{m}^{2}\end{array}$} & \multicolumn{5}{|c|}{ Poljoprivredno zemljište i MSP } \\
\hline & & \multirow{2}{*}{$\begin{array}{r}\text { MSP } \\
\mathrm{m}^{2}\end{array}$} & \multicolumn{2}{|c|}{ Razminirano } & \multicolumn{2}{|c|}{ Nerazminirano } \\
\hline & & & $\mathrm{m}^{2}$ & $\%$ & $\mathrm{~m}^{2}$ & $\%$ \\
\hline Drniš & 19513900 & 1378243 & 489459 & 35,51 & 888784 & 64,49 \\
\hline Promina & 9604100 & 595113 & 153083 & 25,72 & 442030 & 74,28 \\
\hline Ružić & 7409500 & 616016 & 542374 & 88,04 & 73642 & 11,96 \\
\hline Vrlika & 10899100 & 413660 & 0 & 0 & 413660 & 100 \\
\hline Hrvace & 9296500 & 1174908 & 332125 & 28,27 & 842783 & 71,73 \\
\hline Sinj & 24179000 & 0 & 0 & & 0 & \\
\hline Civljane & 2217500 & 0 & 0 & & 0 & \\
\hline Muć & 6348300 & 0 & 0 & & 0 & \\
\hline Ukupno & 89467900 & 4177940 & 1517041 & 36,31 & 2660899 & 63,69 \\
\hline
\end{tabular}

* Podaci Državnog zavoda za statistiku (www.dzs.hr, posjećeno 5. 4. 2010.)

Izvor: Geoinformacijski sustav i baza podataka HCR-a (stanje siječanj 2010.)

Tablica 6 sadrži podatke o strukturi minski sumnjivoga prostora prema namjeni zemljišta. Najviše prostora unutar minski sumnjivoga prostora čine pašnjaci sa $46,40 \%$ udjela i krš s udjelom od $47,49 \%$ ukupnoga minski sumnjivoga prostora. Velik udio minski sumnjivoga prostora koji se odnosi na pašnjake i krš nalazi se na području gradova Drniša i Vrlike te općina Ružić i Hrvace. To može imati negativan utjecaj na bavljenje stočarstvom tek kada se dogodi potpuni povratak izbjegloga stanovništva. Problem tek postoji za ljetne ispaše na otvorenim višim nadmorskim visinama na području Svilaje i Dinare, odnosno uz zimske ispaše u poljima oko Perućkog jezera i Moseća za rijetka i mala obiteljska gospodarstva. Udio nerazminiranoga prostora koji se odnosi na poljoprivredne površine iznosi $4,41 \%$ od ukupne poljoprivredne površine za koju se procjenjuje da je onečišćena minama. Na području Grada Sinja te općina Civljane i Muć poljoprivredno je zemliǰše potpuno očišćeno. Stoga se može pretpostaviti da su neki drugi razlozi presudni u ekstenzivnom bavljenju poljoprivredom. To je prije svega nezadovoljavajuća dobna struktura 
DRUŠ. ISTRAŽ. ZAGREB GOD. 21 (2012)

BR. 1 (115)

STR. 259-275

ČERINA, J.:

ONEČIŚĆENOST.. stanovništva, odnosno visok udio stanovništva starijeg od 65 godina, manjak interesa šire zajednice za poticanje proizvodnje, stihijski uzgoj poljoprivrednih kultura bez kontakta i ispitivanja tržišta. Mlado stanovništvo nema dovoljno motiva za ostanak $u$ ruralnom području, a povezanost poljoprivrede $u$ Dalmatinskoj zagori i ruralnoga turizma kojim bi se oživio prostor nije $u$ većoj mjeri prihvaćeno.

\begin{tabular}{|c|c|c|c|c|c|c|c|c|c|}
\hline \multirow{3}{*}{$\begin{array}{l}\text { Općina / } \\
\text { Grad }\end{array}$} & \multicolumn{9}{|c|}{ Struktura minski sumnjivoga prostora prema namjeni zemljišta } \\
\hline & \multirow{2}{*}{$\begin{array}{r}\text { MSP } \\
\mathrm{m}^{2}\end{array}$} & \multicolumn{2}{|c|}{ Poljoprivredno } & \multicolumn{2}{|c|}{ Pašnjaci } & \multicolumn{2}{|c|}{ Kršs } & \multicolumn{2}{|c|}{ Ostalo } \\
\hline & & $\mathrm{m}^{2}$ & $\%$ & $\mathrm{~m}^{2}$ & $\%$ & $\mathrm{~m}^{2}$ & $\%$ & $\mathrm{~m}^{2}$ & $\%$ \\
\hline rnišs & 31 & 784 & 4,37 & 1040 & 51,22 & 8 & 40,20 & 297 & 4,21 \\
\hline romin & 3 & 30 & 11,96 & 677 & 16,56 & & 68,26 & 19229 & 3,22 \\
\hline Ružić & 79951 & 72647 & 0,92 & 133 & 79 & & 19,42 & 898 & 0,01 \\
\hline rlika & 0 & & 3,39 & 898 & 30 & 8 & 5 & 42593 & 0,35 \\
\hline Hrvace & 15038642 & 842783 & 5,60 & 5160 & 46,05 & 050 & 48,31 & 5649 & 0,04 \\
\hline Sinj & 0 & 0 & 0 & 0 & 0 & 0 & 0 & 0 & 0 \\
\hline Civljaı & 296 & 0 & 0 & 0 & 0 & 296 & 100 & 0 & 0 \\
\hline Muć & 816446 & 0 & 0 & 0 & 0 & 816446 & 100 & 816446 & 0 \\
\hline Ukupno & 60310383 & 660899 & 4,41 & 27983616 & 46,40 & 28642202 & 47,4 & 840112 & 1,70 \\
\hline
\end{tabular}

Izvor: Geoinformacijski sustav i baza podataka HCR-a (stanje siječanj 2010.)

(1) TABLICA 6

Struktura minski sumnjivoga prostora prema namjeni zemljišta
Sigurnost kretanja ljudi i roba na području Dalmatinske zagore nije ugrožena, što pokazuju rezultati analize predstavljeni u Tablici 7. Razminirano je $6,49 \mathrm{~km}^{2} \mathrm{u}$ funkciji građanske sigurnosti. Za potrebe sigurnog odvijanja cestovnoga prometa državnim cestama razminiran je prostor veličine $0,79 \mathrm{~km}^{2}$. U pojasu od $100 \mathrm{~m}$ uz državne ceste na promatranom području više nema minski sumnjivoga prostora. Prostori uz lokalne ceste nisu očišćeni na cijelom promatranom području, osim na području Grada Sinja. Opasnost predstavljaju uski pojasevi uz lokalne ceste i pojedini poljski putovi. Još je velik udio nerazminiranoga prostora $\mathrm{u}$ radijusu od $200 \mathrm{~m}$ uz naselja, ali se to uglavnom odnosi na naselja u kojima još nije došlo do masovnoga povratka stanovništva. Stanje minski sumnjivoga prostora po kriteriju sigurnosti pokazuje značajnu opasnost na području Grada Drniša i Općine Hrvace u odnosu na druge općine i gradove na promatranom području. ${ }^{5}$

Prostori oko naselja u koje se masovno vratilo stanovništvo očišćeni su od mina, pa je time ostvarena temeljna pretpostavka za iskorištavanje prostora i u gospodarske svrhe. Ova je analiza pokazala da su prostori uz stambene objekte i prometnice očišćeni i da nema zapreka za bavljenje poljoprivrednom djelatnošću. Ako se pokaže da minski problem onemogućuje razvojni projekt, tada će to područje biti prioritetno za razminiranje. Sada se minski sumnjive površine nalaze na si- 
(1) TABLICA 7

Stanje minski sumnjivoga prostora prema kriteriju sigurnosti gurnoj udaljenosti od tih naselja, najčešće u zoni krša. Lokalnim zajednicama omogućeno je određivanje prioriteta koje se usklađuje na razini pojedine županije i dalje na nacionalnoj razini. Stoga svaka lokalna zajednica treba imati razrađen sustav gospodarskog razvoja i demografske revitalizacije. Stihijski razvoj ne pridonosi nastojanjima da se razminiranje završi u kraćem razdoblju niti da se potakne povratak, odnosno zadržavanje, stanovništva na određenom području.

\begin{tabular}{|c|c|c|c|c|c|c|}
\hline \multirow[b]{3}{*}{ Općina / Grad } & \multirow[b]{3}{*}{$\begin{array}{r}\text { Polazno stanje } \\
\text { MSP-a po kriteriju } \\
\text { sigurnosti, } \mathrm{m}^{2}\end{array}$} & \multicolumn{5}{|c|}{ Stanje minski sumnjivoga prostora prema kriteriju sigurnosti } \\
\hline & & & & minirano & Nera & minirano* \\
\hline & & $\begin{array}{r}200 \mathrm{~m} \mathrm{uz} \\
\text { naselje, } \mathrm{m}^{2}\end{array}$ & $\begin{array}{r}100 \mathrm{~m} \mathrm{uz} \\
\text { državne } \\
\text { ceste, } \mathrm{m}^{2}\end{array}$ & $\begin{array}{r}50 \mathrm{~m} \mathrm{uz} \\
\text { lokalne } \\
\text { ceste, } \mathrm{m}^{2}\end{array}$ & $\begin{array}{r}200 \mathrm{~m} \mathrm{uz} \\
\text { naselje, } \mathrm{m}^{2}\end{array}$ & $\begin{array}{r}50 \mathrm{~m} \mathrm{uz} \\
\text { lokalne } \\
\text { ceste, } \mathrm{m}^{2}\end{array}$ \\
\hline Drniš & 7664423 & 3520580 & 0 & 514065 & 3116720 & 513058 \\
\hline Promina & 1026780 & 462402 & 0 & 57829 & 243334 & 263215 \\
\hline Ružić & 1163910 & 577595 & 0 & 20298 & 517493 & 48524 \\
\hline Vrlika & 1313736 & 235971 & 0 & 0 & 1077765 & 0 \\
\hline Hrvace & 3490557 & 1448108 & 684224 & 184402 & 1088629 & 85194 \\
\hline Sinj & 306289 & 201891 & 104398 & 0 & 0 & 0 \\
\hline Civljane & 0 & 0 & 0 & 0 & 0 & 0 \\
\hline Muć & 156543 & 40097 & 0 & 0 & 116446 & 0 \\
\hline Ukupno & 15122238 & 6486644 & 788622 & 776594 & 6160387 & 909991 \\
\hline
\end{tabular}

* U pojasu od $100 \mathrm{~m}$ uz državne ceste nema više minski sumnjivoga prostora na promatranom području. Izvor: Geoinformacijski sustav i baza podataka HCR-a (stanje siječanj 2010.)

\section{ZAKLJUČAK}

Dalmatinska zagora je gospodarski zaostao i demografski osiromašen prostor, na kojem su se tijekom Domovinskog rata intenzivirali negativni demografski i gospodarski procesi. Dogodile su se prisilne migracije, a to je pogodilo brojna naselja i rezultiralo depopulacijom i padom tradicijskih djelatnosti. Više su pogođena naselja sa srpskom etničkom većinom, jer se većina predratnoga stanovništva uopće nije vratila. Stanje je složeno i zbog onečišćenosti prostora minama na području gradova Drniša i Vrlike te općina Ružić i Hrvaca. Najviše minski sumnjivoga prostora odnosi se na pašnjake i krš. Problem mina nema osjetnijega utjecaja na bavljenje ruralnim djelatnostima, jer se nije dogodio masovni povratak stanovništva nakon Domovinskog rata. Ujedno, promatrano područje gospodarski je nerazvijeno, u njemu nema u većem broju tržišno usmjerenih gospodarstava. Velik broj malih i sitnih parcela s neriješenim imovinsko-pravnim odnosima i ekstenzivna proizvodnja ne mogu biti poticaj za razvoj poljoprivrede. Problem se javlja tek za ljetne ispaše na području Svilaje i Dinare zbog onečišćenosti prostora minama. 
DRUŠ. ISTRAŽ. ZAGREB GOD. 21 (2012) BR. 1 (115)

STR. $259-275$

ČERINA, J. ONEČIŚĆENOST..

\section{BILJEŠKE}

Sigurnost kretanja ljudi i roba nije ugrožena na promatranom području, jer su očišćeni svi putni pravci i sigurnosni pojasevi uz naselja u koja se vratio život. Onečišćeni prostori uglavnom su pašnjačke površine i krš prekriven makijom, odnosno prostor za koji nije vezano učestalije kretanje stanovništva.

Demografsko i gospodarsko oživljavanje promatranoga područja Dalmatinske zagore moguće je paralelno s procesom razminiravanja i stjecanja osjećaja sigurnosti u obavljanju gospodarskih djelatnosti podalje od naseljenih mjesta. Oživljavanje tradicionalnih aktivnosti još je relativno sporo, ali sve su izraženiji i novi oblici gospodarskih aktivnosti (stacionarni oblik stočarenja i uzgoj goveda), otvaranje novih proizvodnih zona maloga i srednjega poduzetništva, ruralni i ekoturizam. Preduvjet bilo kakvom gospodarskom razvoju kraja jest povratak ne samo izbjegloga stanovništva, koje zbog svoje starosne strukture i ne može biti nosilac bržeg razvoja, nego i privlačenje novoga stanovništva mlađe dobi. Opasnost od mina nije zapreka intenzivnijem bavljenju poljoprivredom (staklenička proizvodnja, stacionarno stočarstvo, hortikultura) koje nadilazi svakodnevne obiteljske potrebe. Problemi su u izostajanju inicijative i nepostojanju jasne strategije razvoja. U tom slučaju strah od mina može poslužiti kao opravdanje za gospodarsku neaktivnost.

Veza s lokalnom zajednicom u procesu protuminskoga djelovanja ima preventivni učinak i pridonosi općoj sigurnosti građana te ublažava socioekonomski utjecaj problema mina. Dok minirani prostori ne budu očišćeni od mina i predani krajnjim korisnicima na sigurnu upotrebu, komunikaciju s lokalnom zajednicom o svim aktivnostima protuminskoga djelovanja treba i nadalje njegovati, s posebnom pažnjom na obilježavanju i provjeri obilježenosti minski sumnjivih područja.

1 Šibenska zagora obuhvaća naselja: Brnjica, Čvrljevo, Goriš, Gradina, Konjevrate i Radonić na području Grada Šibenika; Pakovo Selo, Pokrovnik, Radonić, Sedramić i Žitnić na području Grada Drniša i Cera, Čvrljevo, D. Planjane, D. Utore, D. Vinovo, G. Planjane, G. Utore, G. Vinovo, Koprno, Ljubostinje, Mirlović Zagora, Nevest, Ostrogašica, Podumci, Unešić i Visoka na području Općine Unešić, dok Splitsku zagoru čine naselja: Divojevići, Kladnjice, Lećevica (s. Ublima) i Radošić na području Općine Lećevica; Brštanovo, Dugobabe, Konjsko, Korušce, Nisko, Prugovo, Veliki Broćanac i Vučevica na području Općine Klis; Bogdanovići, Labin, Prgomet, Sitno i Trolokve na području Općine Prgomet; Dugopolje, Koprivno, Kotlenica i Liska na području Općine Dugopolje; Bračević, Crivac, D. Ogorje, D, Postinje, D. Muć, Gizdavac, G. Ogorje, G. Postinje, G. Muć, M. Milešina, Neorić, Pribude, Radunić, Ramljane, Sutina, V. Milišina i Zelovo Sutinsko na području Općine Muć i naselje Primorski Dolac u Općini Primorski Dolac (Matas i Faričić, 2011.). 
DRUŠ. ISTRAŽ. ZAGREB GOD. 21 (2012), BR. 1 (115)

STR. $259-275$

ČERINA, J.: ONEČIŚCENONOST...
2 Preciznije definiranje granica Dalmatinske zagore moguće je pozicioniranjem upravno-teritorijalne nadležnosti područja općina i gradova na topografskim kartama sitnijeg razmjera. Primjerice, prema TK 1:100000, sjeverna granica Dalmatinske zagore odnosi se na liniju Bobija - Rastova kosa.

3 U svome radu Farming minefields: economics of remedialing land with moderate landmine and UXO contamination, Trevelyan i sur. (2002.) među državama onečišćenim minama navode Afganistan, Kambodžu, Vijetnam i Hrvatsku, naglašavajući da su sve to države u kojima je poljoprivreda glavni izvor prihoda, što za Hrvatsku nikako nije točno.

${ }^{4}$ Na području Dalmatinske zagore ima 868 ploča upozorenja na opasnost od mina.

5 Izravna posljedica onečišćenosti prostora minama vidi se u broju nesreća i broju stradalih osoba na području Dalmatinske zagore. Prema podacima dobivenim od HCR-a od 1991. do 1995. godine, dogodilo se 60 nesreća u kojima je smrtno stradalo 27 osoba, a njih je 51 zadobila teške tjelesne ozlijede. Najviše je osoba stradalo na području Općine Hrvace, njih 15, te na području Grada Drniša, gdje je 7 osoba smrtno stradalo, a njih 28 zadobilo je teške tjelesne ozlijede. U zadnjih pet godina nije se dogodila ni jedna nesreća od mina u kojoj bi stradali civili na području Dalmatinske zagore.

\section{LITERATURA}

Arhiva HCR-a: Nacionalni program protuminskog djelovanja za razdoblje 2005. - 2009.

Arhiva HCR-a: Nacionalni program protuminskog djelovanja za razdoblje 2009. - 2019.

Arhiva HCR-a: Plan humanitarnog razminiranja za 2010. godinu.

Benini, A. A., Moulton, H. L. i Conley, C. E. (2002.), Landmines and Local Community Adaptation. Journal of Contingencies and Crisis $\mathrm{Ma}$ nagement, 10 (2): 82-194. doi:10.1111/1468-5973.00184

Bier, G. (2003.), The Economic Impact of Landmines on Developing Countries. International Journal of Social Economics, 30 (5): 651-662.

Bocchina, C. (2007.), Landmines and Conservation in Southern Africa. Peace Parks in the Aftermath of Armed Conflict. African Security Review, 16 (2): 78-93.

Crnički, J. i Šinkovec, B. (1993.), Nemetalne mineralne sirovine Hrvatske. Rudarsko-geološko-naftni zbornik, 5 (1): 21-37.

Čerina, J. (2009.), Doprinos medija sigurnosti građana na primjeru minske opasnosti. Medijski dijalozi, 2 (2): 31-41.

Čerina, J. i Zgrabljić Rotar, N. (2009.), Communication in Crises and Media: Press Coverage on Landmine Accidents. Medijska istraživanja, 15 (1): 143-163.

Filippino, E. (2000.), Implementing Landmine Awareness Programs. The Journal of ERW and Mine Action, 4 (3).

GICHD (2004.), A Guide to Mine Action, Geneva, Geneva International Centre for Humanitarian Demining. 
DRUŠ. ISTRAŽ. ZAGREB GOD. 21 (2012), BR. 1 (115)

STR. $259-275$

ČERINA, J. ONEČIŚCEENOST..
Hewitt, A., Lee-Archer, P. i Studd, B. (2001.), Living with Landmines in Cambodia, Observation and Opinions, University of Tasmania, Hobart, December 2000 - January 2001.

Internetska stranica Državnog zavoda za statistiku http://www.dzs.hr (posjećeno 10. 5. 2010.).

Matas, M. (2005.), O Zagori i njenim demografskim obilježjima. U: M. Matas (ur.), Josip Roglić: Jadranske teme, Sabrana djela (str. 271-288), Split, Geografsko društvo Split.

Matas, M. (2009.), Kladnjice - Prilog poznavanja sela Dalmatinske zagore. U: M. Matas (ur.), Ante Konstantin Matas - Njegovo vrijeme $i$ djelo (str. 131-172), Split, Geografsko društvo Split.

Matas, M. i Faričić, J. (2011.), Uvodne napomene i terminološke odrednice. U: M. Matas i J. Faričić (ur.), Zagora između stočarsko - ratarske tradicije te procesa litoralizacije i globalizacije, Split, Sveučilište u Zadru i Matica Hrvatska Split (u tisku).

Ministarstvo poljoprivrede i šumarstva (1996.), Pravilnik o vinu, 11. XI. 1996.

Trevelyan, J. P., Tilli, S., Parks, B. i Teng Han Chiat (2002.), Farming Minefields: Economics of Remediating Land with Moderate Landmine and UXO Contamination. Demining Technology Information Forum Journal, Humanitarian Demining Research and Development Overview Papers, http://maic.jmu.edu/dtif/OVERVIEW/index.html (28. 5. 2010.)

Vupenyu, D. (2004.), Disenfranchisement at Large: Transfrontier Zones, Conservation and Local Livelihoods, Harare, IUCN ROSA.

Weyl, U. (1999.), Opportunities for an Integrated Demining Strategy in Rural Areas. Mine Action Information Centre Journal, 3 (1), http://maic. jmu.edu/journal/3.1/index.htm (posjećeno 28. 5. 2010.)

\section{Mine Contamination in the Context of Civil Safety and Development in Dalmatian Zagora}

Josip ČERINA

Croatian Mine Action Centre - Regional Office Zadar, Zadar

The paper analyses the relation of mine suspected areas and agricultural activity in the Dalmatian Zagora region. Apart from mines, another problem is that numerous arable areas are covered with weed and macchia due to long-standing neglect. Therefore, future social and economic development is not possible without the help of the larger community. By analysing the mine issue, in relation to civil safety, an answer has been found on how to reduce the influence of mine suspected areas on the life and work of the local population. By classification and description methods, with the help of geo-information tools, categories and the size of the areas 
DRUŠ. ISTRAŽ. ZAGREB GOD. 21 (2012), BR. 1 (115)

STR. $259-275$

ČERINA, J.:

ONEČIŚĆENOST... cleaned from the mine-explosive remnants of war were determined for each endangered community. That enabled further qualitative analyses of the influence of the mine problem on civil safety and economic development. For data processing, the Maplnfo software was used. The belt along the road infrastructure has been cleaned and it enables safe traffic regulation, as opposed to mountain and field roads that are still mined.

Keywords: mine problem, traditional activities, civil safety 